\title{
Estimation of air quality degradation due to Saharan dust at Nouakchott, Mauritania, from horizontal visibility data
}

\author{
Pierre Ozer • \\ Mohamed Béchir Ould Mohamed Laghdaf • \\ Sidi Ould Mohamed Lemine · Jean Gassani
}

Received: 12 December 2005 / Accepted: 26 March 2006

(C) Springer Science + Business Media B.V. 2006

\begin{abstract}
It is now irrefutable that air pollution caused by large amounts of Total Suspended Particulates (TSP) and respiratory particulates or Particulate Matter less than $10 \mu \mathrm{m}$ in aerodynamic diameter $\left(\mathrm{PM}_{10}\right)$ has numerous undesired consequences on human health. Air quality degradation far from the African continent, in the US and in Europe, caused by high concentrations of African dust, is seen as a major threat even though most of these countries are very distant from the Sahara. Surprisingly, no estimates of TSP or $\mathrm{PM}_{10}$ levels near the Saharan dust source are available. Based on horizontal visibility observations which are reduced by the presence of dust in the atmosphere, TSP and $\mathrm{PM}_{10}$ levels are estimated throughout the year 2000 at NouakchottAirport, Mauritania, using relations found in the literature. It appears that concentrations of particles are
\end{abstract}

P. Ozer $(\bowtie)$

Department of Environmental Sciences and Management (DSGE), University of Liege, Avenue de Longwy 185,

B-6700 Arlon, Belgium

e-mail: pozer@ulg.ac.be

M. B. O. M. Laghdaf · S. O. M. Lemine

Société des Aéroports de Mauritanie, BP 5605,

Nouakchott, Mauritania

J. Gassani

Department of Environmental Sciences and Management (DSGE), University of Liege, Avenue de Longwy 185, B-6700 Arlon, Belgium; Laboratoire des Sciences de l'Environnement et de l'Aménagement (LSEA), UMR-MA 105 Paysages et Biodiversité, 2, Bd Lavoisier, F-49045

Angers cedex 1, France significant both in terms magnitude and frequency, as the 24-hour $\mathrm{PM}_{10}$ thresholds established by the US EPA National Ambient Air Quality Standards and the EU Limits Values for Air Quality were exceeded 86 and 137 times, respectively. The average annual concentration is far above air quality standards and estimated at $159 \mu \mathrm{g} \mathrm{m}^{-3}$ for TSP and $108 \mu \mathrm{g} \mathrm{m}^{-3}$ for $\mathrm{PM}_{10}$. These very high particulate levels are likely to represent an important public health hazard and should be considered as a major environmental risk.

Keywords Air quality $\cdot \mathrm{TSP} \cdot \mathrm{PM}_{10} \cdot$ Dust storms Horizontal visibility $\cdot$ Sahara $\cdot$ Mauritania

\section{Introduction}

The Sahara significantly contributes to the global injection of mineral dust into the northern hemisphere (Prospero et al., 2002; Washington et al., 2003). Indeed, it is estimated that the Sahara and its margins inject amounts of dust varying between 600 and 900 $10^{6}$ tons into the atmosphere every year (D'Almeida, 1986; Marticorena et al., 1997; Callot et al., 2000). This represents about half of annual global mineral dust production (Ginoux et al., 2004).

Over the last decade, mineral dust has become a major topic in environment studies. The increase of aeolian processes observed in most arid and semi-arid areas of the world over the last decades is thought to be a response to environmental stresses and global 
climate change (Tegen and Fung, 1995; Lancaster, 1996; Rosenfeld et al., 2001; Ozer, 2002).

In addition, there is growing evidence that air pollution caused by increasing concentrations of total suspended particulates (TSP) and respirable particulates (in other words those smaller than $10 \mu \mathrm{m}\left(\mathrm{PM}_{10}\right)$ ) have many environmental consequences from the local to the global scale, as well as an impact on human health. In addition, wind-borne dust may transport bacteria and fungi (Kellogg et al., 2004; Prospero et al., 2005) and can be contaminated with pesticides (O'Hara et al., 2000) or even radioactive (Papastefanou et al., 2001).

Saharan dust is often transported far away from its sources (Middleton and Goudie, 2001). As a result, deteriorations in air quality caused by high concentrations of respirable African mineral dust have been reported in various regions at great distances from the sources, such as the Canary Islands (Viana et al., 2002), Spain (Baldasano et al., 2003; Rodriguez et al., 2001, 2003; Salvador et al., 2004; Vautard et al., 2005), the United Kingdom (Ryall et al., 2002), the Middle East (Alpert and Ganor, 2001), the West Indies (Rajkumar and Chang, 2000) and the south-eastern United States (Prospero, 1999). Such mineral particulate matter air pollution is a serious health threat in various regions of the world because it may promote respiratory infection, cardiovascular disease and other ailments (Bielders et al., 2001; Griffin and Kellogg, 2004).

High concentrations of mineral $\mathrm{PM}_{10}$ may be the cause of morbidity and mortality. Indeed, a $7.66 \%$ increase in respiratory diseases $\left(+1.12 \%\right.$ per $10 \mu \mathrm{g} \mathrm{m}^{-3}$ increase in $\mathrm{PM}_{10}$ ) and a $4.92 \%$ increase in mortality was recorded $\left(+0.72\right.$ per $10 \mu \mathrm{g} \mathrm{m}^{-3}$ increase in $\left.\mathrm{PM}_{10}\right)$ during Mongolian dust outbreaks in Taipei, Taiwan (Chen et al., 2004). As far as the Caribbean island of Trinidad is concerned, African dust clouds have been associated with increased pediatric asthma accident and emergency admissions (Gyan et al., 2005). Surprisingly, however, no measurements of ambient air pollution levels near the Saharan dust sources are available (WHO, 2000; Baldasano et al., 2003).

Based on the reduction of horizontal visibility measurements due to mineral dust in the air, this paper estimates TSP and $\mathrm{PM}_{10}$ concentration levels at the synoptic station of Nouakchott-Airport, Mauritania, during year 2000, using different relations found in the literature. Comparisons with air quality standards from various sources are examined and discussed.

\section{Data}

Meteorological horizontal visibility is used throughout the world to identify air mass characteristics. In synoptic stations, horizontal visibility is observed on a hourly basis and defined as the greatest horizontal distance at which a black object of suitable dimensions, located near the ground can be seen and recognized when observed against a background scattering of hydrometeors (rain, snow, fog, mist) or lithometeors (dust processes) (WMO, 1992). At the synoptic station of Nouakchott-Airport, 16 targets (buildings, towers, mosques, etc.) whose distances were measured from the point of observation are used to estimate horizontal visibility: 6 are located within the first kilometer, 9 are from 1 to 5 kilometers away, while only one is visible over 5 kilometers ( 7.4 kilometers) from the point of observation.

The international synoptic surface observation code (SYNOP code, WMO, 1996) allowed the identification of four classes of dust-related conditions:

1. dust raised from the ground at the time of the observation (SYNOP codes 07 and 08) and reducing horizontal visibility to less than five kilometers (blowing dust);

2. dust storms, resulting from turbulent wind systems carrying particles of dust into the air, at various degrees of intensity (SYNOP codes 09 and 30 to 36) and reducing horizontal visibility to less than one kilometer;

3. dust suspended in the air but not raised from the ground at the time of observation (SYNOP code 06); remnants of earlier deflation events reducing horizontal visibility to less than five kilometers. Dust deposition is noticed at the time of the observation; and

4. haze (SYNOP code 05, presumably caused by dust) reducing horizontal visibility to less than ten kilometers. In this case, no dust deposition is observed which suggests that the dust particles have been raised from the soil a considerable distance away.

Further detailed information on dust related conditions used in the literature can be found in Ozer (2000).

For this study, only dust processes reducing horizontal visibility to five kilometers or less were taken into account. Horizontal visibility was observed on a three-hourly basis, that is at 03:00, 06:00, 09:00, 12:00, 
15:00, 18:00, 21:00, and 24:00 UTC. Other horizontal visibility data were not used because only one target is available above this distance and using it may therefore lead to imprecision in the results.

\section{Methods}

3.1 Relation between horizontal visibility and TSP or $\mathrm{PM}_{10}$

Very few studies on the relation between horizontal visibility and TSP or $\mathrm{PM}_{10}$ levels of mineral dust mass concentration have been carried out in West Africa.

Here, we will refer to previous studies by Ben Mohamed and his colleagues (1992) to estimate TSP mineral dust mass concentrations. These authors used horizontal visibility data varying from 100 meters to 20 kilometers in seven synoptic stations of Niger, over a period of 17 months, and associated TSP mineral dust mass concentration measurements in order to establish a relationship between the two parameters. The relation is:

$C_{\mathrm{TSP}}=1339.84 \mathrm{VV}^{-0.67}$

where $C$ is the TSP concentration in $\mu \mathrm{g} \mathrm{m}^{-3}$ and VV is the horizontal visibility in $\mathrm{km}$.

With regard to $\mathrm{PM}_{10}$ mineral dust mass concentrations, we use D'Almeida's (1986) correlation analysis that links the turbidity of observed aerosols, horizontal visibility and mineral dust mass concentrations. This analysis was developed based on on a turbidity network of 11 stations set up in the Sahara, in the Sahelian belt and in the surrounding southern area over a period of two years (1981 and 1982). The visibilities used range from 200 meters to 40 kilometers and the relation obtained is $\left(r^{2}=0.95\right)$ :

$C_{\mathrm{PM}_{1} 0}=914.06 \mathrm{VV}^{-0.73}+19.03$

where $C$ is the $\mathrm{PM}_{10}$ concentration in $\mu \mathrm{g} \mathrm{m}^{-3}$ and $\mathrm{VV}$ is the horizontal visibility in $\mathrm{km}$.

Comparative suspended mineral dust concentration data for atmospheric dust processes linked with visibility measurements are very scarce in the literature. In Mali, Gillies et al. (1996) have reported a daily atmospheric dust concentration of $13,735 \mu \mathrm{g} \mathrm{m}^{-3}$ measured during a dense dust haze reducing visibility to less than
$100 \mathrm{~m}$. Chung et al. (2003b) monitored sandstorms in Korea and found average TSP concentrations of 659 and $380 \mu \mathrm{g} \mathrm{m}^{-3}$ associated with horizontal visibility reduced to 3 and $5 \mathrm{~km}$ respectively. These data are to the same order as the values derived from the relationship of Ben Mohamed et al. (1992) used in this paper. Visibility reduced to $1.9 \mathrm{~km}$ during a yellow sand storm in Kwangju, Korea, was associated with $\mathrm{PM}_{10}$ concentrations of $602 \mu \mathrm{g} \mathrm{m}^{-3}$. (Kim et al., 2001). For this reduction in visibility, D'Almeida's relation estimates a concentration in $\mathrm{PM}_{10}$ of $591 \mu \mathrm{g} \mathrm{m}^{-3}$.

These two relationships (Equations 1 and 2) are applied to the visibility data of Nouakchott-Airport in order to make TSP and $\mathrm{PM}_{10}$ estimates. The results obtained are presented on a daily, monthly and yearly scale.

\subsection{Air quality regulations}

Several guidelines and regulations have been adopted to define air quality levels. The World Health Organization (WHO) considers Guideline Values (GV), the US Environmental Protection Agency (EPA) defines the National Ambient Air Quality Standards (NAAQS), and the EU labels the Limit Values for Air Quality (LVAQ). A recent compilation of the air quality regulation status around the world shows that no such criteria exist in Africa (Baldasano et al., 2003).

For annual average TSP concentrations, the guideline values to which we will refer fall within a range of 60-90 $\mu \mathrm{g} \mathrm{m}^{-3}$ (WHO, 1979). With regard the $\mathrm{PM}_{10}$, the strictest value is currently $40 \mu \mathrm{g} \mathrm{m}^{-3}$ in the EU and in New Zealand. Elsewhere, where regulations exist, the limit is usually $50 \mu \mathrm{g} \mathrm{m}^{-3}$. In the EU, the limit for annual $\mathrm{PM}_{10}$ will be lowered to $20 \mu \mathrm{g} \mathrm{m}^{-3}$ in 2010 .

As far as daily particulate matter is concerned, TSP concentration has been used to monitor air quality in developed countries during the 1980s and the 1990s and is still used in many developing countries where $\mathrm{PM}_{10}$ concentration measurements are not undertaken. In the USA, a limit of $260 \mu \mathrm{g} \mathrm{m}^{-3}$ has been set that should not to be exceeded more than once per year. For $\mathrm{PM}_{10}$, the EU-LVAQ is the strictest, with a limit of $50 \mu \mathrm{g} \mathrm{m}^{-3}$ that currently should not be exceeded on 35 days per year. This will be reduced to 7 days per year from 2010. Other 24-hour standard concentration limits range from 100 to $150 \mu \mathrm{g} \mathrm{m}^{-3}$ (Baldasano et al., 2003). In the USA, the EPA-NAAQS established that a $150 \mu \mathrm{g} \mathrm{m}^{-3}$ threshold should not be exceeded more 
Table 1 US EPA Air Quality Index (AQI), associated 24-hour $\mathrm{PM}_{10}\left(\mu \mathrm{g} \mathrm{m}^{-3}\right)$ concentration, and health effects (US-EPA, 1999)

\begin{tabular}{|c|c|c|c|}
\hline AQI category & AQI values & $\mathrm{PM}_{10}\left(\mu \mathrm{g} \mathrm{m}^{-3}\right)$ & Health effects \\
\hline Good & $0-50$ & $0-54$ & None \\
\hline Moderate & $51-100$ & $55-154$ & None \\
\hline Unhealthy for sensitive groups & $101-150$ & $155-254$ & $\begin{array}{l}\text { Increasing likelihood of respiratory symptoms and aggravation } \\
\text { of lung disease, such as asthma }\end{array}$ \\
\hline Unhealthy & $151-200$ & $255-354$ & $\begin{array}{l}\text { Increasing likelihood of respiratory symptoms and aggravation } \\
\text { of lung disease, such as asthma; possible respiratory effects } \\
\text { in general population }\end{array}$ \\
\hline Very unhealthy & $201-300$ & $355-424$ & $\begin{array}{l}\text { Significant increase in respiratory symptoms and aggravation of } \\
\text { lung disease, such as asthma; increasing likelihood of } \\
\text { respiratory effects in general population }\end{array}$ \\
\hline Hazardous & $>300$ & $>424$ & $\begin{array}{l}\text { Serious risk of respiratory symptoms and aggravation of lung } \\
\text { disease, such as asthma; respiratory effects likely in general } \\
\text { population }\end{array}$ \\
\hline
\end{tabular}

that once per year, averaged over 3 years. In addition to these daily limits, the US EPA developed the Air Quality Index (AQI) as a tool to provide people with timely and easy-to-understand information on local air quality and whether it poses a health concern (US EPA, 1999). As shown on Table 1, the AQI scale has been divided into six categories, each corresponding to a different level of health concern. The two first AQI categories (good and moderate, $<155 \mathrm{PM}_{10} \mu \mathrm{g} \mathrm{m}^{-3}$ ) have no impact on health, while the last AQI category (hazardous, $>424 \mathrm{PM}_{10} \mu \mathrm{g} \mathrm{m}^{-3}$ ) is associated with a serious risk of respiratory symptoms and aggravation of lung disease, such as asthma, for sensitive groups and with respiratory effects likely in the general population.

Estimated TSP and $\mathrm{PM}_{10}$ concentrations will be systematically compared with threshold values established by WHO-GV, US EPA-NAAQS or EULVAQ.

\section{Results}

4.1 Daily particulate matter concentrations due to Saharan dust

Figure 1 shows the estimated profiles of mean daily TSP and $\mathrm{PM}_{10}$ concentrations due to mineral dust processes at Nouakchott-Airport throughout the year 2000. Horizontal lines indicate the thresholds established for daily concentrations. The greatest number of days with low air quality occurred from January to April. These four months account for $73 \%$ of the yearly number of days above the former US EPA-NAAQS TSP regulation, and 59 and $72 \%$ of the yearly number of days above the 24-hour EU-LVAQ and the US EPA-NAAQS PM 10 regulations, respectively. Two days with an extremely high density of particulate matter are observed on January 28th and 29th with TSP concentrations of 2630 and $2108 \mu \mathrm{g} \mathrm{m}^{-3}$ and $\mathrm{PM}_{10}$ concentrations of 1942 and $1531 \mu \mathrm{g} \mathrm{m}^{-3}$, respectively.

Such very high concentrations are not uncommon during very dense dust storms. In the inland Niger delta region of central Mali, Gillies and his colleagues (1996) have reported a daily atmospheric dust concentration of $13,735 \mu \mathrm{g} \mathrm{m}^{-3}$ measured during a dense dust haze. At Beijing, China, daily TSP concentrations greater than $4000 \mu \mathrm{g} \mathrm{m}^{-3}$ were observed during an explosive sandstorm (Chung et al., 2003a). As regards daily $\mathrm{PM}_{10}$, Chung and his colleagues (2003a) recorded a $1779 \mu \mathrm{g} \mathrm{m}^{-3}$ concentration in Chongwon-Chongju, Korea. Meanwhile, in Beijing, $\mathrm{PM}_{10}$ concentrations above $1000 \mu \mathrm{g} \mathrm{m}^{-3}$ were reported during dust storms (Fang et al., 2003). Finally, $\mathrm{PM}_{10}$ air concentrations exceeding $1800 \mu \mathrm{g} \mathrm{m}^{-3}$ was measured in Kuwait during severe dust storms (Draxler et al., 2001).

The distribution of the number of days with selected pollution gradients is presented in Fig. 2. It shows that 74 days $(20.3 \%)$ presented TSP concentrations above $260 \mu \mathrm{g} \mathrm{m}^{-3}$, the former US EPA-NAAQS TSP regulation (Fig. 2a). At higher levels, 34 days (9.3\%) present an average 24-hour TSP concentration greater than $500 \mu \mathrm{g} \mathrm{m}^{-3}$. 
Fig. 1 Variations of estimated daily mean concentrations of TSP and $\mathrm{PM}_{10}\left(\mu \mathrm{g} \mathrm{m}^{-3}\right)$ due to Saharan dust events at Nouakchott, Mauritania, in 2000
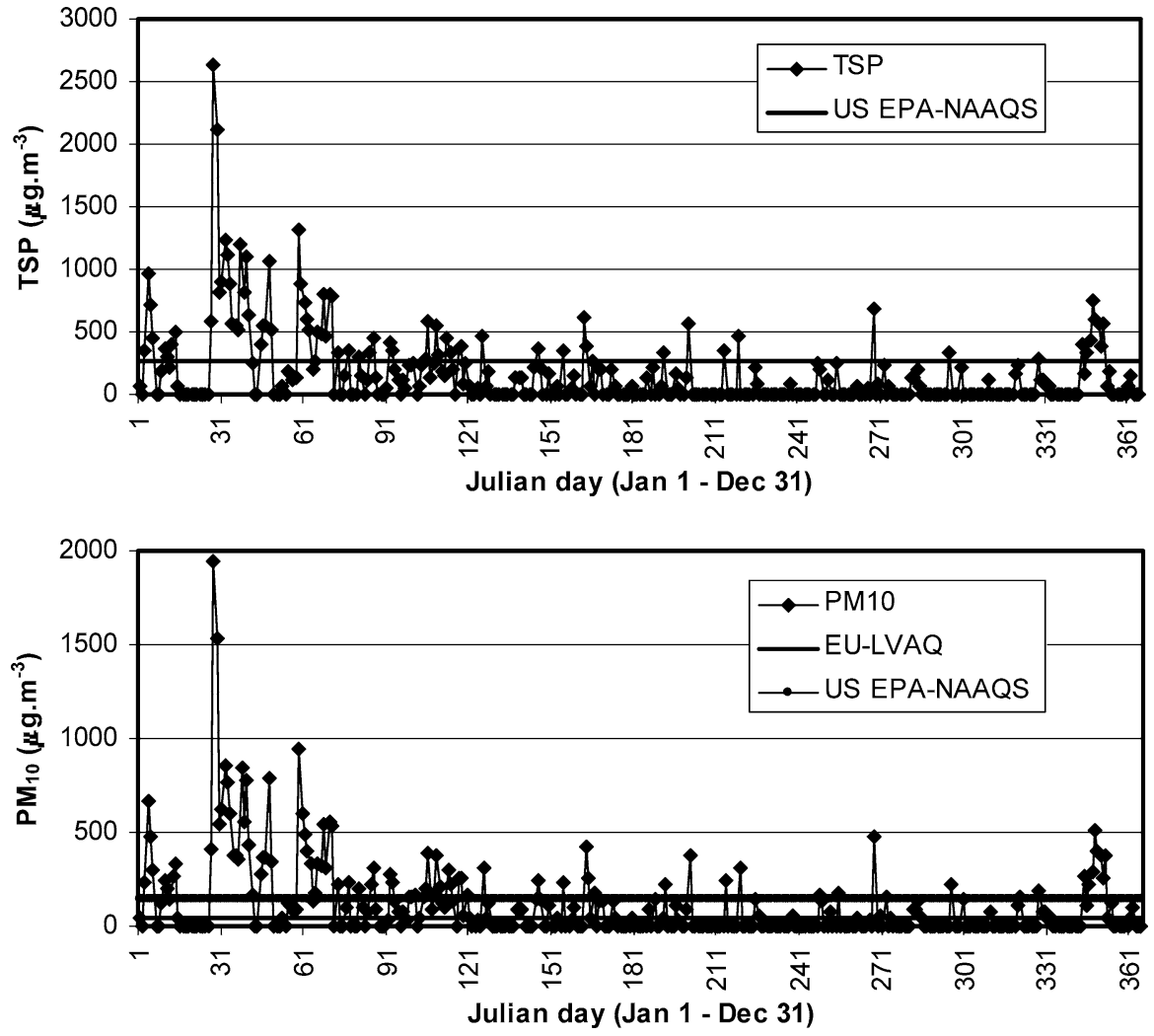
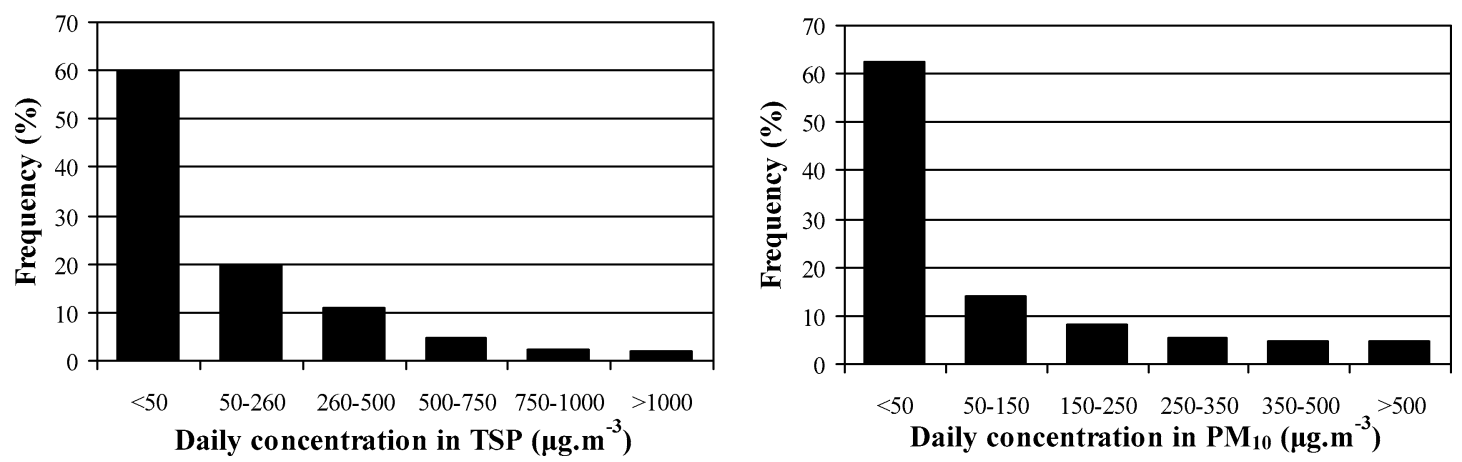

Fig. 2 Distribution of the number of days with selected pollution gradients $\left(\mu \mathrm{g} \mathrm{m}^{-3}\right)$ in TSP (left) and $\mathrm{PM}_{10}$ (right)

Frequency distribution of estimated daily $\mathrm{PM}_{10}$ concentrations at Nouakchott-Airport are shown in Fig. 2b. Results suggest that only $62.5 \%$ of the days were free from mineral dust. Air quality deteriorated during all of the other 137 days, with 51 days in the 50$150 \mu \mathrm{g} \mathrm{m}^{-3}$ range. Compared to the threshold of daily $\mathrm{PM}_{10}$ concentrations established by the EU-LVAQ, the number of polluted days is about four times greater than the permitted number of days with $>50 \mu \mathrm{g} \mathrm{m}^{-3}$, and 20 times higher than the legislation on air quality that shall enter into force by 2010 . When the US EPANAAQS is used, 86 days exceed the $150 \mu \mathrm{g} \mathrm{m}^{-3}$ limit value.

Compared to the US EPA-AQI, 29 days (7.9\%) may be considered as unhealthy for sensitive groups, 19 days $(5.2 \%)$ as unhealthy, 13 days $(3.6 \%)$ as very unhealthy and 22 other days $(6.0 \%)$ may be qualified as hazardous. A total of $22.7 \%$ of the days were therefore 


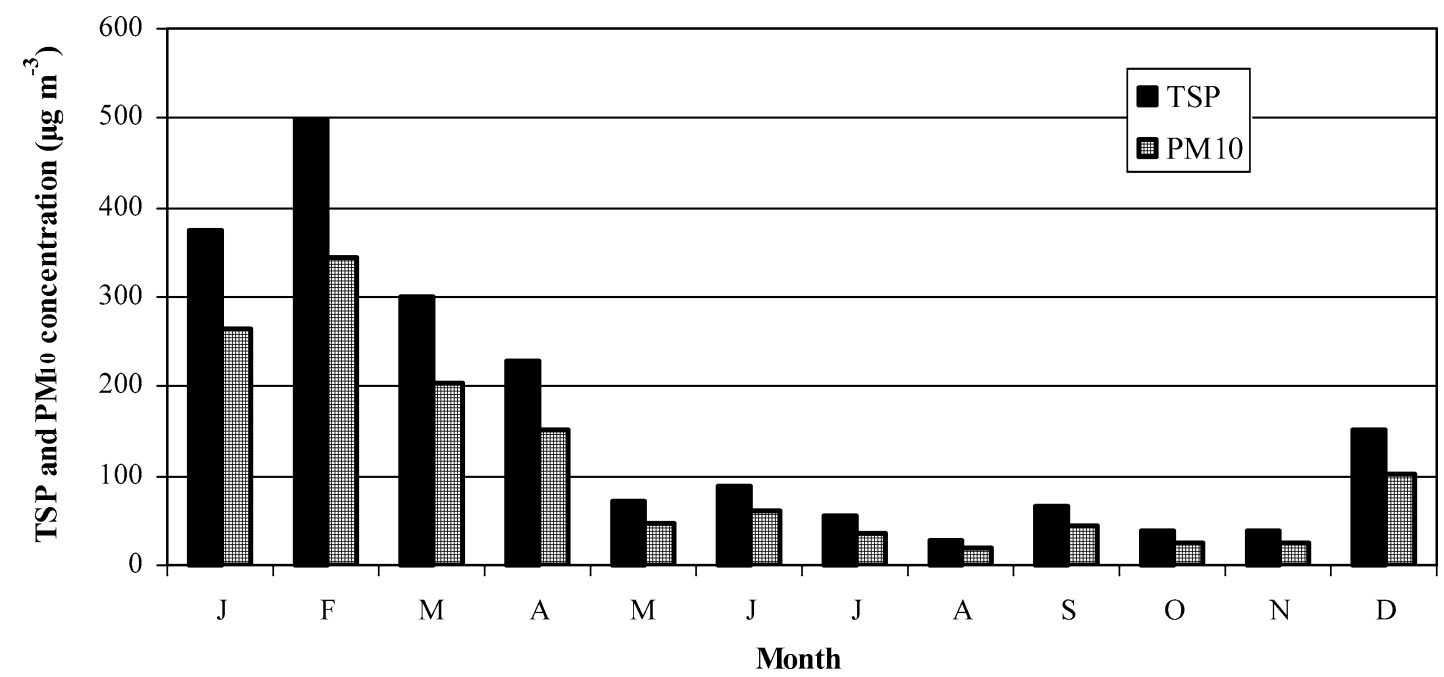

Fig. 3 Monthly concentration in TSP and $\mathrm{PM}_{10}\left(\mu \mathrm{g} \mathrm{m}^{-3}\right)$ at Nouakchott-Airport during 2000

likely to impact human health in Nouakchott during the year 2000 because of the high frequency of mineral dust processes.

4.2 Monthly and seasonal TSP and $\mathrm{PM}_{10}$ values due to Saharan dust

Monthly TSP and $\mathrm{PM}_{10}$ values estimated at Nouakchott-Airport for 2000 are presented in Fig. 3. Results show that air quality degradation due to Saharan dust varies a great deal throughout the year. A maximum value is recorded during the months of January to March which concentrate $61 \%$ of annual mineral dust air pollution. Monthly values are above $300 \mu \mathrm{g} \mathrm{m}^{-3}$ and $200 \mu \mathrm{g} \mathrm{m}^{-3}$, with a maximum concentration observed in February: $497 \mu \mathrm{g} \mathrm{m}^{-3}$ and $344 \mu \mathrm{g} \mathrm{m}^{-3}$ in TSP and $\mathrm{PM}_{10}$, respectively. A decline in dust activity then starts in April $\left(227 \mu \mathrm{g} \mathrm{m}^{-3}\right.$ and $153 \mu \mathrm{g} \mathrm{m}^{-3}$ in TSP and $\left.\mathrm{PM}_{10}\right)$ and remains relatively low $\left(<60 \mu \mathrm{g} \mathrm{m}^{-3}\right.$ in $\mathrm{PM}_{10}$ ) from May to November, with a minimum value in August $\left(27 \mu \mathrm{g} \mathrm{m}^{-3}\right.$ and $18 \mu \mathrm{g} \mathrm{m}^{-3}$ in TSP and $\left.\mathrm{PM}_{10}\right)$. December shows an increase in dusty days and gives monthly values of $150 \mu \mathrm{g} \mathrm{m}^{-3}$ and $101 \mu \mathrm{g} \mathrm{m}^{-3}$ in TSP and $\mathrm{PM}_{10}$. A similar monthly pattern of estimated TSP and $\mathrm{PM}_{10}$ concentrations has been observed in Niamey, Niger, where the January to March period represents $65 \%$ of annual mineral dust air pollution, with monthly values ranging from 230 to $330 \mu \mathrm{g} \mathrm{m}^{-3}$ in TSP and from 160 to $200 \mu \mathrm{g} \mathrm{m}^{-3}$ in $\mathrm{PM}_{10}$ (Ozer, 2005).
Similarly high monthly $\mathrm{PM}_{10}$ concentrations (100 to $200 \mu \mathrm{g} \mathrm{m}^{-3}$ ) were measured in Iraq, Kuwait and Saudi Arabia during the dust season (Draxler et al., 2001). On the Aral Sea shore, monthly PM $_{10}$ concentrations up to $400 \mu \mathrm{g} \mathrm{m}^{-3}$ were reported in August, the most intense sand storm period (Wiggs et al., 2003).

\subsection{Annual TSP and $\mathrm{PM}_{10}$ values due to Saharan dust}

The annual mean estimated TSP concentration is 159 $\mu \mathrm{g} \mathrm{m}^{-3}$ at Nouakchott-Airport in 2000 for natural dust exposure only. This figure is twice as high as the annual WHO guideline value of $60-90 \mu \mathrm{g} \mathrm{m}^{-3}$ (WHO, 1979). It is also slightly higher than the $137 \mu \mathrm{g} \mathrm{m}^{-3}$ mean annual TSP concentration measured in Accra, Ghana, the only comparable information available for West-Africa (Baldasano et al., 2003). However, when compared to mean annual values of TSP available elsewhere in the world, our data is systematically below the measurements made in large Asian cities of China, India, Indonesia and Iran, as well as in few cities of South America (Baldasano et al., 2003).

In relation to $\mathrm{PM}_{10}$ concentration, our calculations yield a value of $108 \mu \mathrm{g} \mathrm{m}^{-3}$ in 2000 . This figure is far above the norms adopted in developed countries. It is twice the threshold value established by the US EPA-NAAQS and five times higher than the limit of the EU-LVAQ yearly mean $\mathrm{PM}_{10}$ concentration that shall enter into force by 2010. No comparison can be made with other African data as no measurements are 
available from the recent compilation of air quality data realized by Baldasano et al. (2003). However, the estimated annual mean $\mathrm{PM}_{10}$ concentration from visibility impairments in Niamey, Niger, was $67 \mu \mathrm{g} \mathrm{m}^{-3}$ in 2003 (Ozer, 2005). From other annual mean $\mathrm{PM}_{10}$ concentrations reported by Baldasano et al. (2003), only the city of Tegucigalpa, Honduras, exceeds the Nouakchott value, with $157 \mu \mathrm{g} \mathrm{m}^{-3}$. It is worth mentioning here that no records of $\mathrm{PM}_{10}$ concentration are available in arid regions from developing countries.

Such values do not estimate the urban air pollution of the city of Nouakchott where the activities of a rapidly growing urban population $(558,000$ inhabitants in 2000 against 135,000 in 1977, WWW1) produce large quantities of particulate matter. This urban air pollution mainly results from increasing traffic of old and badly maintained vehicles on sandy roads, and from individual fires for cooking purposes.

\section{Conclusions}

The results presented in this study give a first estimation of the impact of mineral dust resulting from aeolian processes on air quality degradation in Nouakchott, Mauritania, throughout the year 2000. A mean annual TSP concentration of $159 \mu \mathrm{g} \mathrm{m}^{-3}$, largely above the $\mathrm{WHO}-\mathrm{GV}$, is alarming since only natural particulates are considered. A similar conclusion can be drawn for the mean annual $\mathrm{PM}_{10}$ concentration of $108 \mu \mathrm{g} \mathrm{m}^{-3}$ which dramatically exceeds all various norms established in developed countries. Daily $\mathrm{PM}_{10}$ concentrations exceeded $1500 \mu \mathrm{g} \mathrm{m}^{-3}$ on two occasions in 2000. The EU-LVAQ 24-hour limit for $\mathrm{PM}_{10}$ concentration $\left(>50 \mu \mathrm{g} \mathrm{m}^{-3}\right.$ ) was exceeded on 137 days. This is about 20 times higher than the limit outlined in the legislation on air quality that shall enter into force in the EU by 2010. The $150 \mu \mathrm{g} \mathrm{m}^{-3}$ limit value established by the US EPA-NAAQS was exceeded 86 times, with 22 days that may be qualified as hazardous according to the US EPA-AQI.

Developed countries are building up strategies in order to reduce air pollution. However, most African countries have neither air quality regulations, nor the tools to monitor air pollution. It is widely accepted that acute respiratory infections among children are one of the major causes of mortality in developing countries, especially in Africa (Black et al., 2003; Romieu et al., 2002; Smith et al., 1999). However, no studies on the impact of mineral dust concentrations on human health have been carried out in West Africa due to the lack of air quality data. Estimations of TSP and $\mathrm{PM}_{10}$ concentrations derived from horizontal visibility observations could be a first step in realizing such studies.

\section{References}

Alpert, P., \& Ganor, E. (2001). Sahara mineral dust measurements from TOMS: comparison to surface observations over the Middle East for the extreme dust storm, March 14-17, 1998. Journal of Geophysical Research, 106, 18275-18286.

Baldasano, J.M., Valera, E., \& Jiménez, P. (2003). Air quality data from large cities. The Science of the Total Environment, 307, 141-165.

Ben Mohamed, A., Frangi, J.P., Fontan, J., \& Druilhet, A. (1992). Spatial and temporal variations of atmospheric turbidity and related parameters in Niger. Journal of Applied Meteorology, 31, 1286-1294.

Bielders, C.L., Alvey, S., \& Cronyn, N. (2001). Wind erosion: the perspective of grass-roots communities in the Sahel. Land Degradation and Development, 12, 57-70.

Black, R.E., Morris, S.S., \& Bryce, J. (2003). Where and why are 10 million children dying every year? Lancet, 361, 22262234.

Callot, Y., Marticorena, B., \& Bergametti, G. (2000). Geomorphologic approach for modelling the surface features of arid environments in a model of dust emissions: applications to the Sahara desert. Geodinamica Acta, 13, 245-270.

Chen, Y.S., Sheen, P.C., Chen, E.R., Liu, Y.K., Wu, T.N., \& Yang, C.Y. (2004). Effects of Asian dust storms events on daily mortality in Taipei, Taiwan. Environmental Research, 95, 151-155.

Chung, Y.S., Kim, H.S., Dulam, J., \& Harris, J.: 2003a. On heavy dustfall observed with explosive sandstorms in ChongwonChongju, Korea in 2002. Atmospheric Environment, 37, 3425-3433.

Chung, Y.S., Kim, H.S., Park, K.H., Jhun, J.G., \& Chen, S.J.: 2003b. Atmospheric loadings, concentrations and visibility associated with sandstorms: satellite and meteorological analysis. Water, Air, and Soil Pollution, Focus, 3, 21-40.

D'Almeida, G.A. (1986). A model for Saharan dust transport. Journal of Climate and Applied Meteorology, 25, 903916.

Draxler, R.R., Gillette, D.A., Kirkpatrick, J.S., \& Heller, J. (2001). Estimating $\mathrm{PM}_{10}$ air concentrations drom dust storms in Iraq, Kuwait and Saudi Arabia. Atmospheric Environment, 35, 4315-4330.

Fang, X., Xie, Y., \& Li, L. (2003). Effects of duststorms on the air pollution in Beijing. Water, Air, and Soil Pollution, Focus, 3, 93-101.

Gillies, J.A., Nickling, W.G., \& McTainsh, G.H. (1996). Dust concentrations and particle-size characteristics of an intense dust haze event: inland delta region, Mali, West Africa. Atmospheric Environment, 30, 1081-1090.

Ginoux, P., Prospero, J.M., Torres, O., \& Chin, M. (2004). Long-term simulation of global dust distribution with the 
GOCART model: correlation with North Atlantic Oscillation. Environmental Modelling \& Software, 19, 113-128.

Griffin, D.W., \& Kellogg, C.A. (2004). Dust storms and their impact on ocean and human health: dust in earth's atmosphere. Ecohealth, 1, 284-295.

Gyan, K., Henry, W., Lacaille, S., Laloo, A., Lamsee-Ebanks, C., McKay, S., Antoine, R.M., \& Monteil, M.A. (2005). African dust clouds are associated with increased paediatric asthma accident and emergency admissions on the Caribbean island of Trinidad. International Journal of Biometeorology, 49, 371-376.

Kellogg, C.A., Griffin, D.W., Garrison V.H., Peak K.K., Royall N., Smith R.R., \& Shinn, E.A. (2004). Characterization of aerosolized bacteria and fungi from desert dust events in Mali, West Africa. Aerobiologia, 20, 99-110.

Kim, K.W., Kim, Y.J., \& Oh, S.J. (2001). Visibility impairment during Yellow Sand periods in the urban atmosphere of Kwangju, Korea. Atmospheric Environment, 35, 51575167.

Lancaster, N. (1996). Preface: response of aeolian processes to global climate change. Geomorphology, 17, 1-2.

Marticorena, B., Bergametti, G., Aumont, B., Callot, Y., N'Doumé, C., \& Legrand, M. (1997). Modeling the atmospheric dust cycle: 2. Simulation of Saharan dust sources. Journal of Geophysical Research, 102, 4387-4404.

Middleton, N.J., \& Goudie, A.S. (2001). Saharan dust: sources and trajectories. Transactions of the Institute of British Geographers, 26, 165-181.

O'Hara, S.L., Wiggs, G.F.S., Mamedov, B., Davidson, G., \& Hubbard, R.B. (2000). Exposure to airborne dust contaminated with pesticide in the Aral Sea region. Lancet, 355, 627-628.

Ozer, P. (2000). Les lithométéores en région sahélienne: un indicateur climatique de la désertification. GEO-ECO-TROP, $24,1-317$.

Ozer, P. (2002). Dust variability and land degradation in the Sahel. BELGEO, 2, 195-209.

Ozer, P. (2005). Estimation de la pollution particulaire naturelle de l'air en 2003 à Niamey (Niger) à partir de données de visibilité horizontale. Environnement, Risques \& Santé, 4, 43-49.

Papastefanou, C., Manolopoulou, M., Stoulos, S., Ioannidou, A., \& Gerasopoulos, E. (2001). Coloured rain dust from Sahara desert is still radioactive. Journal of Environmental Radioactivity, 55, 109-112.

Prospero, J.M. (1999). Long-term measurements of the transport of African mineral dust to the southeastern United States: Implications for regional air quality. Journal of Geophysical Research, 104, 15917-15927.

Prospero, J.M., Blades, E., Mathison, G., \& Naidu, R. (2005). Interhemispheric transport of viable fungi and bacteria from Africa to the Caribbean with soil dust. Aerobiologia, 21, 1-19.

Prospero, J.M., Ginoux, P., Torres, O., Nicholson, S.E., \& Gill, T.E. (2002). Environmental characterization of global sources of atmospheric soil dust identified with the NIMBUS 7 Total Ozone Mapping Spectrometer (TOMS) absorbing aerosol product. Review of Geophysics, 40, 1002, doi: 10.1029/2000RG000095.

Rajkumar, W.S., \& Chang, A.S. (2000). Suspended particulate matter concentrations along the East-West Corridor,
Trinidad, West Indies. Atmospheric Environment, 34, 1181-1187.

Rodriguez, S., Querol, X., Alastuey, A., Kallos, G., \& Kakaliagou, O. (2001). Saharan dust contributions to PM10 and TSP levels in southern and eastern Spain. Atmospheric Environment, 35, 2433-2447.

Rodriguez, S., Querol, X., Alastuey, A., Viana, M., \& Mantilla, E. (2003). Events affecting levels and seasonal evolution of airborne particulate matter concentrations in the western Mediterranean. Environmental Science \& Technology, 37, 216-222.

Romieu, I., Samet, J.M., Smith, K.R., \& Bruce, N. (2002). Outdoor air pollution and acute respiratory infections among children in developing countries. Journal of Occupational and Environmental Medicine, 44, 640-649.

Rosenfeld, D., Rudich, Y., \& Lahav, R. (2001). Desert dust suppressing precipitation: a possible desertification feedback loop. Proceeding of the National Academy of Sciences, 98, 5975-5980.

Ryall, D.B., Derwent, R.G., Manning, A.J., Redington, A.L., Corden, J., Millington, W., Simmonds, P.G., O'Doherty, S., Carslaw, N., \& Fuller, G.W. (2002). The origin of high particulate concentrations over the United Kingdom, March 2000. Atmospheric Environment, 36, 1363-1378.

Salvador, P., Artíñano, B., Alonso, D.G., Querol, X., \& Alastuey, A. (2002). Identification and characterisation of sources of $\mathrm{PM}_{1} 0$ in Madrid (Spain) by statistical methods. Atmospheric Environment, 38, 435-447.

Smith, R.K., Corvalán, C.F., \& Kjellström, T. (1999). How much global ill health is attributable to environmental factors? Epidemiology, 10, 573-584.

Tegen, I., \& Fung, I. (1995). Contribution to the atmospheric mineral aerosol load from land surface modification. Journal of Geophysical Research, 100, 18707-18726.

US EPA (1999). Guideline for reporting of daily air quality Air Quality Index (AQI). Office for Air Quality Planning and Standards, United States Environmental Protection Agency, North Carolina, USA. http://www.epa.gov/ttn/oarpg/t1/memoranda/rg701.pdf. Last accessed August, 27, 2005.

Vautard, R., Bessagnet, B., Chin, M., \& Menut, L. (2005). On the contribution of natural Aeolian sources to particulate matter concentrations in Europe: testing hypotheses with a modelling approach. Atmospheric Environment, 39, 3291-3303.

Viana, M., Querol, X., Alastuey, A., Cuevas, E., \& Rodriguez, S. (2002). Influence of African dust on the levels of atmospheric particulates in the Canary Islands air quality network. Atmospheric Environment, 36, 58615875.

Washington, R., Todd, M., Middleton, N.J., \& Goudie, A.S. (2003). Dust-storm source areas determined by the Total Ozone Monitoring Spectrometer (TOMS) and surface observations. Annals of the Association of American Geographers, 93, 299-315.

WHO (1979). Sulfur oxides and suspended particulate matter. Geneva, Switzerland: Environmental Health Criteria 8, World Health Organization.

WHO (2000). Guidelines for air quality. Geneva, Switzerland: World Health Organization.

Wiggs, G.F.S., O’Hara, S.L., Wegerdt, J., van der Meer, J., Small, I., \& Hubbard, R. (2003). The dynamics and characteristics 
of aeolian dust in dryland Central Asia: possible impacts on human exposure and respiratory health in the Aral Sea basin. Geographical Journal, 169, 142-157.

WMO (1992). International Meteorological Vocabulary. Geneva, Switzerland: World Meteorological Organization.
WMO (1996). Guide to meteorological instruments and methods of observation. Geneva, Switzerland: World Meteorological Organization.

WWW1. http://www.ons.mr/stat/population/pop1.html. Last accessed April 27, 2005. 